\title{
Retraction:
}

\section{Gynura procumbens extract improves insulin sensitivity and suppresses hepatic gluconeogenesis in $\mathrm{C} 57 \mathrm{BL} / \mathrm{KsJ}-d b / d b$ mice}

\author{
Sung-In Choi ${ }^{1}$, Hyun-Ah Lee ${ }^{1}$ and Ji-Sook Han ${ }^{1,2 \S}$ \\ 'Department of Food Science and Nutrition, Pusan National University, Jangjeon 2-dong, Geumjeong-gu, Busan 46241, Korea \\ ${ }^{2}$ Research Institute of Ecology for the Elderly, Pusan National University, Busan 46241, Korea
}

Nutrition Research and Practice 2019;13(1):76; https://doi.org/10.4162/nrp.2019.13.1.76; pISSN 1976-1457 elSSN 2005-6168

The editors of Nutrition Research and Practice received a letter of raising concerns regarding this paper ${ }^{1)}$. In response, NRP's special committee on research ethics launched an investigation. During an investigation, authors admitted unintentionally omitting citations for an article that had been previously published in J. Clin. Biochem. Nutr'). The entire article has been retracted from NRP in accordance with NRP policy and editorial decision.

This article has been retracted by agreement between the authors and YoonJu Song/Sang-Jin Chung (Editors-in-Chief).

The online version of the original article can be found at https://doi.org/10.4162/nrp.2016.10.5.507

\section{REFERENCES}

1. Choi SI, Lee HA, Han JS. Gynura procumbens extract improves insulin sensitivity and suppresses hepatic gluconeogenesis in C57BL/KsJ-db/db mice. Nutr Res Pract. 2016;10(5):507-515.

2. Park CJ, Lee HA, Han JS. Jicama (Pachyrhizus erosus) extract increases insulin sensitivity and regulates hepatic glucose in C57BL/Ksj-db/db mice. J Clin Biochem Nutr. 2016 Jan; 58(1):56-63. 